\title{
Entrepreneurship and Work Motivation Training Towards Entrepreneurial Interest in Arowana Fish Pond
}

\author{
Mashudi $^{*}$, Rustam1, Riama Al Hidayah ${ }^{1}$, \& Erwin sutandar ${ }^{2 *}$ \\ 1 Faculty of Teacher Training and Education, University of Tanjungpura, \\ Prof. Dr. Hadari Nawawi Pontianak street, West Kalimantan, Indonesia. \\ ${ }^{2}$ Faculty of Civil Engineering, University of Tanjungpura, \\ Prof. Dr. Hadari Nawawi Pontianak street, West Kalimantan, Indonesia. \\ E-mail: profdrmashudi@gmail.com; Erwin_sutandar@yahoo.com \\ *Corresponding author details: Mashudi; profdrmashudi@gmail.com, \\ Erwin sutandar; Erwin_sutandar@yahoo.com
}

\begin{abstract}
The research objectives are to describe the effect of entrepreneurship training towards entrepreneurial interest, to describe the effect of work motivation towards entrepreneurial interest, and to describe the effect of entrepreneurship training and work motivation towards entrepreneurial interest. The business world needs strong young entrepreneurs, especially in the era of globalization, persistence skill, strong interest attitude in being able to compete in business world. Training or practice is alternative solution that can be chosen to build the mindset of young generation of Selimbau. Entrepreneurship is cultivated through the spirit of entrepreneurship, the ability to take risks, the ability to read opportunity. According to Kuratko (2018:5), Entrepreneurship must be done, tried, implemented because it is a dynamic process of vision, change and creation. Entrepreneurial interest arises from oneself or will not arise by itself suddenly from within the individual. Interest can grow or arise in a person through an external process or influence. The method used in this research is ex post facto of entrepreneurial training variables (16 items), work motivation (14 items) and entrepreneurial interest (15), with population of 51 . The approach used is qualitative and multiple regression analysis.
\end{abstract}

Keywords: entrepreneurship training; work motivation; entrepreneurial interest

\section{INTRODUCTION}

The business world needs strong young entrepreneurs, especially in the era of globalization, skills, persistence, and a strong interest attitude to be able to compete in the business world. On the other hand, the younger generation of Selimbau work to face the challenges of global competition while the employment is limited. Moreover, the competition in looking for job is getting tighter and the unemployment rate is high. (Valerio, Parton, \& Robb, 2014) entrepreneurship training as a program that leads, focuses on building knowledge, skills and confidence explicitly in preparation to start a business, because this training program guides participants to engage in entrepreneurial work practices to train business development, thereby fostering the entrepreneurial interest, and be able to plan to carry out a program of business activity.

The training or practice that is carried out is an alternative solution that can be chosen to build the mindset of younger generation of Selimbau who previously have not had an entrepreneurial interest or have not met the standards of an entrepreneur. Then after taking entrepreneurial training or practice the young generation of Selimbau can be ready mentally, thought and financially and be able to compete in the business market. Entrepreneurship training plays an important role in developing creativity, initiative, innovation and applicability that will result in satisfaction and prosperity. Self-confidence to grow and develop in the business sector for the younger generation of Selimbau can reduce unemployment, because they create jobs, alleviate the poverty of people, avoid the economic downturns.
Therefore, an entrepreneurial spirit or interest in entrepreneurship is not a talent from birth, but a potential that is developed in daily life, both entrepreneurial interest and from the existing business environment. Based on that experience, they learn about entrepreneurship knowledge, how to become a successful entrepreneur, how to cultivate a person's entrepreneurial spirit and how to foster entrepreneurial interest.

Entrepreneurship is cultivated through the spirit to enterprise, the ability to take risks, and the ability to read opportunity. In accordance with opinion of (Kuratko, 2018) Entrepreneurship must be done, tried, implemented because it is a dynamic process of vision, change and creation. It requires innovation, creativity, rational action, passionate economical action, optimistic and enthusiast about the creation and implementation of new ideas and creative solutions. Important thing include a willingness to take risks that include time, fund, or career; the ability to formulate effective business activities; the ability to find and collect needed resources; those are main and fundamental skills to build a proper business activity; and finally, a vision to find a way or recognize business opportunities, while others see it as an impossible, difficult, contradictory and confusing activity.

Proactive, high and very confident work motivation must be existing in someone who wants to be a successful entrepreneur, because the existence of motivation or encouragement of strong and high confidence will create 
and build the mentality of young generation of Selimbau to always be superior and do everything beyond the existing standard. Work motivation is also an important factor in evoking entrepreneurial interest. Motivation may come from oneself or from others. (Munandar, 2014) argues that person's work motivation can be more proactive or reactive. In proactive work motivation, people will strive to improve their skills according to the demand of work and will always try, create, find, and be able to read opportunities where they can use their skill to perform well on work. On the other hand, a reactive person's work motivation shows and tends to wait for efforts or offers from other people or environment. They are forced to work if there is an urge (external). Work motivation or a strong willingness to complete the process in determining the level of activity, intensity, consistency, and path to be achieved, so as to create behavior that related to interest, attitudes and so on to be consistent. Everyone has different motivations to fulfill their desire but with the entrepreneurial training and practice, supported with by work motivation and strong willingness, then entrepreneurial interest will arise and then be able to plan and do an enterprise.

In the previous study conducted by (Dorgan, 2015), succeeded to prove the positive effect of entrepreneurship education given to the Turkish University students towards entrepreneurial interest as one of the career option. In line with the previous research conducted by (Pitiasari, 2016) entitled "The Effect of Entrepreneurship Training on Motivation and Family Environment towards Entrepreneurial Interest in Students of Management Study Program, Faculty of Economics, University of Nusantara PGRI Kediri". The research succeeded in proving that there was an effect of entrepreneurship training and motivation towards entrepreneurial interest, meaning that the better and conducive the training and motivation carried out, causing the students to increasingly have a high and optimal entrepreneurial interest.

The training conducted for the younger generation in Selimbau, Suhad Subdistrict, Kapuas Hulu, is to train the younger generation that graduates from SMK Generasi Muda Selimbau, in order to have business knowledge and can be developed and competencies, to foster the entrepreneurial interest. According to (Kurniati, 2018), two factors that affect the entrepreneurial interest are intrinsic factors (from within oneself) and extrinsic factors (from outside oneself). Intrinsic factors include: self-motivation, need for income, self-esteem, pleasure feelings. Extrinsic factors include: encouragement from others, environment, educational/training opportunities.

Entrepreneurial interest may arise from oneself or will not arise suddenly from within the individual. Interest can foster through a process or external influence. The presence of entrepreneurship training that is deliberately given as external influence will build motivation, attention and interaction with the environment, so that entrepreneurial interest can develop. According to (Suryana, 2006, p. 18) "entrepreneurial interest is a tendency of the will in a person to be interested to create an enterprise which then organizes it, manages it, ready to take risks and can develop the enterprise that has been created". With the foster entrepreneurial interest, younger generations are eager to explore the potential and every resource of them. "Interest is a tendency to persist to observe and remember certain activities. Someone who is interested in his desired activity will pay attention consistently with a sense of pleasure and responsibility" (Djamarah, 2015). A person's interest is not a given gift from birth, but can foster and develop due to the influence of the surrounding environment.
Interest shows a feeling of preference, pleasure and feeling of interest in a thing or activity, without being told or forced. Interest is very influential in achieving achievement and success in study, work, position, or career. People who have no interest or desire will not make effort or not excited, not interested, care in carrying out a job.

Based on the description that has been explained, researcher is interested in conducting a research to younger generation of Selimbau Nanga Suhaid, namely "The Effect of Entrepreneurship Training and Work Motivation towards Entrepreneurial Interest in Arowana Fish Pond". The problems to be investigated are 1) whether there is an effect of entrepreneurship training towards entrepreneurial interest, 2) whether there is an effect of work motivation towards entrepreneurial interest, 3) whether there is an effect of training and work motivation towards entrepreneurial interest.

Training is a process that includes a set of actions (efforts) carried out deliberately in providing assistance to the workforce, which are younger generation of Selimbau (SMK graduates) done by professionals in a particular field of work to increase effectiveness and productivity in an organization. Training "is an activity to increase the ability of employees in an institution, so that training is a process that will result a change in behavior of the employees" (Notoatmodjo, 2009, p. 19). Training is a practice of the environment of a process that teaches knowledge and expertise as wll as attitudes so that the younger generation of Selimbau will be more skilled and able to carry out their responsibilities better, in accordance with business standard. Entrepreneurship is a result of a very disciplined and systematic process in implementing work steps with creativity and innovation to the needs and opportunities in the market (Zimmerer, Scarborough, \& Wilson, 2008). This includes implementing a focused strategy towards new ideas and perspectives to create opportunities, products, or serves that satisfy the needs of customer or solve business problems. Valerio, Parton, \& Robb (2014) defines entrepreneurship training as a program that tends to focus on building knowledge and skills explicitly in preparation for starting a business, which is in this training program guides participants to engage in practice. Therefore, motivation is an encouragement to carry out behavioral activities to work in an effort to fulfill the desired needs, so the work motivations for someone can be more proactive or reactive. In proactive work motivation people will try to improve their ability according to their job demands and will try, find and create opportunities where they can use their ability to be able to do a really good job. On the other hand, reactive work motivation tends to wait for an effort or an offer from the environment. They work if being encouraged, forced (from outside) to work. "Motivation is an impulse that is arranged by a purpose and rarely appears in a void. Understanding work motivation is very important because it results in performance, leads to reactions towards compensation and other human source issues" (Mathis \& Jackson, 2016, p. 115).

\section{METHOD}

The method used in this research is ex post facto. Sukmadinata (2017, p. 52) argues: "research methods is a series of ways or activities to carry out research based on basic assumptions, philosophical views and ideological questions and issues". In accordance with the problems to be studied, the method used in this research is Ex Post Facto. Ex Post Facto research is a research conducted to examine an event or phenomenon that had happened, then backward observations will be conducted about what factors caused the incident or study. 
The research approach used is a quantitative approach with the aim to describe a problem or a situation based on the influence between the independent variable and the dependent variable using descriptive statistical calculations. Data analysis used is multiple regression analysis with SPSS Version 22.0 for windows towards entrepreneurship training variable using 6 indicators, 5 alternative Likert scale with 16 question items, and entrepreneurial interest using 4 indicators, 15 questions from 51 respondents of population.

\section{FINDING AND DISCUSSION}

\section{Finding}

The questionnaire used as the main instrument aims to prove the hypothesis through statistical testing. The statistical data that were tested came from 3 variables, namely: entrepreneurial training variable (X1) with 6 indicators containing 16 questions, work motivation variable (X2) with 4 indicators containing 14 questions, the entrepreneurial interest varies $(\mathrm{Y})$ with 4 indicators containing 15 questions.
Measurement of this variable uses a Likert scale with a maximum score of 5 and a minimum of 1 with computer assistance, namely the SPSS version 22.0 for windows program.

To ensure the accuracy of the tools used, a validity test was carried out on the research instrument. The data validity test is done by comparing $r$ count (Pearson correlation value) with $r$ table (obtained from table $r$ ). if $r$ count is positive and $r$ count $>r$ table then the statement is declared valid. Meanwhile, if $r$ count is negative, and $r$ count $<r$ table then the statement is declared invalid. The total statements in the questionnaire of this study were 45 statements with 51 respondents

The results of the validity test of this instrument can be seen in table 1, table 2 and table 3 as follows

TABLE 1: Results of the Validity Test of the Entrepreneurship Training Instrument (X1)

\begin{tabular}{|c|c|c|c|}
\hline No item & R account & R table & Annotation \\
\hline Item 1 & 0,465 & 0,361 & Valid \\
\hline Item 2 & 0,488 & 0,361 & Valid \\
\hline Item 3 & 0,741 & 0,361 & Valid \\
\hline Item 4 & 0,602 & 0,361 & Valid \\
\hline Item 5 & 0,481 & 0,361 & Valid \\
\hline Item 6 & 0,729 & 0,361 & Valid \\
\hline Item 7 & 0,819 & 0,361 & Valid \\
\hline Item 8 & 0,741 & 0,361 & Valid \\
\hline Item 9 & 0,649 & 0,361 & Valid \\
\hline Item 10 & 0,436 & 0,361 & Valid \\
\hline Item 11 & 0,689 & 0,361 & Valid \\
\hline Item 12 & 0,649 & 0,361 & Valid \\
\hline Item 13 & 0,658 & 0,361 & Valid \\
\hline Item 14 & 0,842 & 0,361 & Valid \\
\hline Item 15 & 0,658 & 0,361 & 0,361 \\
\hline Item 16 & 0,417 & 2020 & \\
\hline
\end{tabular}

Source: SPSS Output Test Instrument Validity (X1) 2020

TABLE 2: Results of the Validity Test of Work Motivation Instruments (X2)

\begin{tabular}{|c|c|c|c|}
\hline $\begin{array}{c}\text { Item } \\
\text { number }\end{array}$ & R account & R table & annotation \\
\hline Item 1 & 0,819 & 0,361 & Valid \\
\hline Item 2 & 0,828 & 0,361 & Valid \\
\hline Item 3 & 0,754 & 0,361 & Valid \\
\hline Item 4 & 0,819 & 0,361 & Valid \\
\hline Item 5 & 0,460 & 0,361 & Valid \\
\hline Item 6 & 0,750 & 0,361 & Valid \\
\hline Item 7 & 0,643 & 0,361 & Valid \\
\hline Item 8 & 0,572 & 0,361 & Valid \\
\hline Item 9 & 0,773 & 0,361 & Valid \\
\hline Item 10 & 0,643 & 0,361 & Valid \\
\hline Item 11 & 0,572 & 0,361 & Valid \\
\hline Item 12 & 0,754 & 0,361 & Valid \\
\hline Item 13 & 0,754 & 0,361 & 0,361 \\
\hline Item 14 & 0,819 & & \\
\hline
\end{tabular}

Source: SPSS Output Test Instrument Validity (X2) 2020 
TABLE 3: Results of the Validity Test of Entrepreneurial Interest Instruments (Y)

\begin{tabular}{|c|c|c|c|}
\hline No item & R hitung & R tabel & Keterangan \\
\hline Item 1 & 0,524 & 0,361 & Valid \\
\hline Item 2 & 0,715 & 0,361 & Valid \\
\hline Item 3 & 0,576 & 0,361 & Valid \\
\hline Item 4 & 0,449 & 0,361 & Valid \\
\hline Item 5 & 0,760 & 0,361 & Valid \\
\hline Item 7 & 0,832 & 0,361 & Valid \\
\hline Item 8 & 0,742 & 0,361 & Valid \\
\hline Item 9 & 0,702 & 0,361 & Valid \\
\hline Item 10 & 0,434 & 0,361 & Valid \\
\hline Item 11 & 0,649 & 0,361 & Valid \\
\hline Item 12 & 0,702 & 0,361 & Valid \\
\hline Item 13 & 0,623 & 0,361 & Valid \\
\hline Item 14 & 0,873 & 0,361 & Valid \\
\hline Item 15 & 0,594 & 0,361 & Valid \\
\hline Item 16 & 0,411 & 0,361 & \\
\hline
\end{tabular}

Source: SPSS Output Test Instrument Validity (Y) 2020

The results of the validity test in this study indicate that all items (45 statements) are declared valid. Based on this data, entrepreneurial training instruments, work motivation instruments and entrepreneurial interest instruments are declared valid and proper to use

The normality test is carried out before the regression analysis, which aims to determine whether the regression, both the dependent variable and the independent variable, has a normal distribution or not. Calculate normality using the help of SPSS version 22 for windows.

The sample normality test in this study was shown by the One-Sample Kolmogorov-Smirnov statistical test (K-S test) with the help of SPSS version 22 for windows. The formulation of the hypothesis used is:

Ho = Data comes from a population that is not normally distributed

$\mathrm{Ha}=$ Data comes from populations with normal distribution

With the decision making are:

(1) If the significance value $>a$ then Ha is accepted

(2) If the significance value $<\mathrm{a}$ then $\mathrm{Ha}$ is rejected

If the significance at the Kolmogorov-Smirnov value $<0.05$, then $\mathrm{Ha}$ is rejected, so the data is not normally distributed. If the significance at the Kolmogorov-Smirnov value $>0.05$, then Ha is accepted, so the data is normally distributed. The results of the normality test (Kolmogorov-Smirnov test) can be seen in table 4.9 as follows
TABLE 4: Results of the Kolmogorov-Smirnov One-Sample Test

\begin{tabular}{|c|c|c|}
\cline { 3 - 3 } \multicolumn{2}{c|}{} & $\begin{array}{c}\text { Unstandardized } \\
\text { Residual }\end{array}$ \\
\hline \multirow{2}{*}{$\begin{array}{c}\text { Normal } \\
\text { Parameters } a, b\end{array}$} & Mean & 51 \\
\cline { 2 - 3 } & $\begin{array}{c}\text { Std. } \\
\text { Deviation }\end{array}$ & 1,42442206 \\
\hline \multirow{2}{*}{$\begin{array}{c}\text { Most Extreme } \\
\text { Differences }\end{array}$} & Absolute & 0,118 \\
\cline { 2 - 3 } & Positive & 0,060 \\
\cline { 2 - 3 } & Negative & $-0,118$ \\
\hline \multicolumn{2}{|c|}{ Test Statistic } & 0,118 \\
\hline \multicolumn{2}{|c|}{ Asymp. Sig. (2-tailed) } &, 076 c,d \\
\hline
\end{tabular}

Source: Primary data processed, 2020

Based on the results of the normality test (KolmogorovSmirnov test) in table 4 shows that the Asymp.Sig. (2tailed) significance value is (0.076). This shows that the significance value is greater than the confidence value $(a=$ 0.05). Therefore, it can be concluded that Ho is rejected and the variable data accepts $\mathrm{Ha}$, so that the variables are normally distributed and pass the normality test.

Then, the heteroscedasticity test was conducted. The heteroscedasticity test aims to test whether in the regression model there is an inequality of variance from the residuals of one observation to another. A good regression model is homoscedasticity or heteroscedasticity does not occur. The way to detect whether there is heteroscedasticity or not is by using the Glejser test. Symptoms that indicate the occurrence of heteroscedasticity are if the significant value of the independent variables is $<0.05$, there is heteroscedasticity, and if the significance value of the independent variables> 0.05 then there is no symptom of heteroscedasticity. The heteroscedasticity test results can be seen in the following table: 
TABLE 5: Heteroscedasticity Test Results

\begin{tabular}{|c|c|c|c|c|c|c|}
\hline \multirow{2}{*}{ Model } & \multicolumn{2}{|c|}{ Unstandardized Coefficients } & $\begin{array}{c}\text { Standardized } \\
\text { Coefficients }\end{array}$ & \multirow{2}{*}{ t } & \multirow{2}{*}{ Sig. } \\
\cline { 2 - 6 } & B & Std. Error & Beta & \\
\hline \multirow{2}{*}{1} & 1,975 & 1,286 & & 1,536 & 0,131 \\
\cline { 2 - 6 } & $\begin{array}{c}\text { Entrepreneurship } \\
\text { training }\end{array}$ & $-0,006$ & 0,015 & $-0,069$ & $-0,438$ & 0,663 \\
\cline { 2 - 6 } & Work motivation & $-0,010$ & 0,014 & $-0,111$ & $-0,701$ & 0,486 \\
\hline
\end{tabular}

Source: Primary data processed, 2020

Based on table 5, it is known that the significance value of the entrepreneurial training variable is $0.663>0.05$ so it can be concluded that the regression model does not contain heteroscedasticity. The significance value of the work motivation variable is $0.486>0.05$, it can be concluded that the regression model does not contain heteroscedasticity.

The multiple regression model is good for explaining the dependent variable, that is, it does not contain multicollinearity, that is, there is no perfect relationship between the independent variables.
This test aims to determine whether each independent variable is linearly related. The multicollinearity test can be seen from the Variance Inflation Factor (VIF) and the tolerance value. Multicollinearity occurs if the tolerance value is $<0.10$ or equal to VIF $>10$. If none of the VIF values exceed 10 , it can be said that the multicollinearity value that occurs is not dangerous (passes the multicollinearity test). The multicollinearity test results (VIF test) in this study are as follows:

TABLE 6: Multicollinearity Test Results

\begin{tabular}{|c|c|c|c|c|c|c|c|c|}
\hline & \multirow{2}{*}{ Model } & \multicolumn{2}{|c|}{$\begin{array}{c}\text { Unstandardized } \\
\text { Coefficients }\end{array}$} & \multirow{2}{*}{$\begin{array}{c}\begin{array}{c}\text { Standardized } \\
\text { Coefficients }\end{array} \\
\text { Beta }\end{array}$} & \multirow{2}{*}{$\mathbf{t}$} & \multirow{2}{*}{ Sig. } & \multicolumn{2}{|c|}{$\begin{array}{c}\text { Collinearity } \\
\text { Statistics } \\
\end{array}$} \\
\hline & & B & $\begin{array}{l}\text { Std. } \\
\text { Error }\end{array}$ & & & & Tolerance & VIF \\
\hline \multirow{3}{*}{1} & (Constant) & 5,401 & 2,115 & & 2,554 & 0,014 & & \\
\hline & $\begin{array}{l}\text { Entrepreneurship } \\
\text { training }\end{array}$ & 0,481 & 0,024 & 0,889 & 19,762 & 0,000 & 0,826 & 1,211 \\
\hline & Work motivation & 0,460 & 0,023 & 0,889 & 19,762 & 0,000 & 0,826 & 1,211 \\
\hline
\end{tabular}

Source: Processed data, 2020

Based on the results of the multicollinearity test (VIF test) in table 6, it can be seen that in the Coefficients section, it can be seen that the VIF of entrepreneurial training is 1.211 and the VIF of work motivation is 1.211 , which is less than 10 , and the Tolerance of entrepreneurship training is 0.826 and the Tolerance of work motivation is 0.826 which is close to the figure. 1 and nothing less than 0.10 . So, it can be said that this regression model does not have multicollinearity.
The linearity test aims to determine whether the independent variables X1 and X2 have a linearity or not significant relationship with the dependent variable Y. Tests on SPSS using the For Linearitaty Test at a significance level of 0.05 . The results of linearity testing can be seen as follows:

TABLE 7: Results of the Linearity Calculation Test X1 to Y

\begin{tabular}{|c|c|c|c|c|c|c|c|}
\hline & & & $\begin{array}{c}\text { Sum of } \\
\text { Squares }\end{array}$ & Df & $\begin{array}{c}\text { Mean } \\
\text { Square }\end{array}$ & $\mathbf{F}$ & Sig. \\
\hline \multirow{5}{*}{$\begin{array}{l}\text { Entrepreneurship } \\
\text { training } \\
\text { Work motivation }\end{array}$} & \multirow{3}{*}{$\begin{array}{c}\text { Between } \\
\text { Groups }\end{array}$} & (Combined) & 820,706 & 20 & 41,035 & 2,764 & 0,006 \\
\hline & & Linearity & 339,155 & 1 & 339,155 & 22,847 & 0,000 \\
\hline & & $\begin{array}{l}\text { Deviation } \\
\text { from } \\
\text { Linearity } \\
\end{array}$ & 481,551 & 19 & 25,345 & 1,707 & 0,092 \\
\hline & \multicolumn{2}{|c|}{ Within Groups } & 445,333 & 30 & 14,844 & & \\
\hline & \multicolumn{2}{|c|}{ Total } & 1266,039 & 50 & & & \\
\hline
\end{tabular}

Source: SPSS Linearity Test Output Results, 2020

Based on table 7, the results of the calculation of the linearity test data for entrepreneurship training (X1) on the interest in entrepreneurship (Y), the coefficient of Flinierity $<\mathrm{F}$ table is obtained, namely
$1.707<3.19$ and deviation from linearity $0.092>$ 0.05 . So, it can be concluded that there is a linear relationship between entrepreneurial training variables and entrepreneurial interest. 
TABLE 8: Results of the Linearity Test for $X 2$ against $Y$

\begin{tabular}{|c|c|c|c|c|c|c|c|}
\hline & & & $\begin{array}{l}\text { Sum of } \\
\text { Squares }\end{array}$ & Df & $\begin{array}{c}\text { Mean } \\
\text { Square }\end{array}$ & $\mathbf{F}$ & Sig. \\
\hline \multirow{5}{*}{$\begin{array}{l}\text { Entrepreneurship } \\
\text { training } \\
\text { Work motivation }\end{array}$} & \multirow{3}{*}{$\begin{array}{l}\text { Between } \\
\text { Groups }\end{array}$} & (Combined) & 733,089 & 21 & 34,909 & 1,900 & 0,054 \\
\hline & & Linearity & 339,165 & 1 & 339,165 & 18,455 & 0,000 \\
\hline & & $\begin{array}{l}\text { Deviation } \\
\text { from } \\
\text { Linearity } \\
\end{array}$ & 393,925 & 20 & 19,696 & 1,072 & 0,424 \\
\hline & \multicolumn{2}{|c|}{ Within Groups } & 532,950 & 29 & 18,378 & & \\
\hline & \multicolumn{2}{|c|}{ Total } & $1,266,039$ & 50 & & & \\
\hline
\end{tabular}

Source: SPSS Linearity Test Output Results, 2020

Based on table 8, from the results of the calculation of work motivation linearity test data (X2) on interest in entrepreneurship (Y), it is obtained that the coefficient of Linearity $<\mathrm{F}$ table is $1.072<3.19$ and deviation from linearity is $0.424>0.05$.
So, it can be concluded that there is a linear relationship between work motivation and interest in entrepreneurship.

Based on the calculation of multiple linear regression analysis using the SPSS version 22 for windows program, it can be seen in table 9 below:

TABLE 9: Regression Equation Model and Partial Test Coefficients a

\begin{tabular}{|c|l|c|c|c|c|c|}
\hline \multirow{2}{*}{ Model } & \multicolumn{2}{|c|}{ Unstandardized Coefficients } & $\begin{array}{c}\text { Standardized } \\
\text { Coefficients }\end{array}$ & \multirow{2}{*}{ T } & \multirow{2}{*}{ Sig. } \\
\cline { 2 - 6 } & B & Std. Error & Beta & & 0,014 \\
\hline \multirow{2}{*}{1} & (Constant) & 5,401 & 2,115 & & 2,554 & 0,000 \\
\cline { 2 - 7 } & $\begin{array}{l}\text { Entrepreneurship } \\
\text { training }\end{array}$ & 0,481 & 0,024 & 0,889 & 19,762 & 0,000 \\
\cline { 2 - 7 } & Work motivation & 0,460 & 0,023 & 0,889 & 19,762 & \\
\hline
\end{tabular}

Source: Processed data, 2020

Based on the table 9 above, the regression equation is obtained:

$\mathrm{Y}=5.401+0.481 \mathrm{X} 1+0.460 \mathrm{X} 2+$ error. Through the equation above, it can be seen that every increase of 0.481 score for entrepreneurship training will be followed by an increase in work motivation by 0.460 .

The hypothesis is a temporary answer used by researchers to the formulation of problems in research. For this reason, the provisional answer must be tested for empirically correctness. There are three hypotheses in this study using multiple linear regression analysis. Multiple linear regression analysis functions to determine the influence either individually (partially) or jointly (simultaneously) between the independent variables, namely entrepreneurship training and work motivation on the dependent variable, namely interest in entrepreneurship. The following is the result of calculations with multiple linear regression using the SPSS version 22 for windows program.

(1) t test or partial test

The $t$ test is used to determine the effect of each independent variable partially on the dependent variable based on Table 9 Coefficients, for testing the first hypothesis using the $t$ test. The first hypothesis testing is done by comparing the results of $t$ and $t$ table. From table 9 the coefficient is partially known that the $t$-count value is 19.762 with a probability of $0.000<0.05$ for the entrepreneurial training variable. Meanwhile, for the ttable with a significance level of $5 \%$, the $t$-table value was 2.01 . The comparison between the two results in tcount> ttable, $(19.762>2.01)$
The results above indicate that $t$ count is greater than $t$ table. Thus, the test results show receiving $\mathrm{Ha}$. The magnitude of the direct influence of the entrepreneurial training variable on entrepreneurial interest, namely:

$\mathrm{X} 1 \rightarrow \mathrm{Y}=\rho \mathrm{YX} 1=(0,889 \mathrm{x} 0,889)=0.7903=79,03 \%$.

The results of these calculations indicate the magnitude of the contribution of the influence of entrepreneurship training on the interest in entrepreneurship is $79.03 \%$, while the rest $(100 \%-79.03 \%=20.97 \%)$ is influenced by other factors not examined.

Furthermore, based on Table 9 Coefficient, for testing the second hypothesis using the $t$ test. The second hypothesis testing is done by comparing the results of $t$ and $t$ table. From table 9 Coefficients, it is known that the 5\% significance level is obtained by a t-table value of 2.01 . The comparison between the two results in tcount $>$ ttable, namely $19.762>2.01$.

The results above indicate that $t$ count is greater than $t$ table. Thus, the test results show receiving Ha. Therefore, it can be concluded that, from these results, it shows that the work motivation variable itself (partially) has a positive and significant direct effect on interest in entrepreneurship.

The magnitude of the direct influence of the work motivation variable on the interest in entrepreneurship, namely:

$\mathrm{X} 2 \rightarrow \mathrm{Y}=\rho \mathrm{YX} 2=(0,889 \times 0,889)=0,7903$ atau $79,03 \%$.

The results of these calculations show that the contribution of work motivation to the interest in entrepreneurship is $79.03 \%$, while the rest $(100 \%$ $79.03 \%=20.97 \%$ ) is influenced by other factors not examined in this study. 
(2) F Test or Simultaneous Test

Simultaneously the two independent variables were tested for meaning using the $\mathrm{F}$ test.
The results of calculations using the SPSS version 22 for windows program are shown in Table 10 below:

TABLE 10: $\mathrm{F}$ Test Results

\begin{tabular}{|c|c|c|c|c|c|}
\hline \multicolumn{2}{|c|}{ Sum of Squares } & Def & Mean Square & F & Sig. \\
\hline Regression & $1,164,590$ & 2 & 582,295 & 275,510 &, $000^{\mathrm{b}}$ \\
\hline Residual & 101,449 & 48 & 2,114 & & \\
\hline Total & $1,266,039$ & 50 & & & \\
\hline R & R Square & \multicolumn{2}{|c|}{ Adjusted R Square } & $\begin{array}{c}\text { Std. Error of the } \\
\text { Estimate }\end{array}$ \\
\hline 959a & 0,920 & \multicolumn{3}{c|}{0,917} & 1,454 \\
\hline
\end{tabular}

Source: Processed data 2020

The third hypothesis testing is done by using the F test, which is a test that is carried out jointly (simultaneously) between the entrepreneurial training variables and work motivation on entrepreneurial interest. From table 10 ANOVA, it can be obtained a probability significance value of 0.000 and a of 0.05 . Because the significance value is smaller than the alpha value $(0.000<0.05)$, it can be concluded that Ho is rejected and accepts Ha.

Testing the third hypothesis can also be done by comparing the results of Fcount with Ftable. From the results of the simultaneous test in Table 10 ANOVA, it is obtained that the Fcount value is 275.510. For Ftable with a significance level of $5 \%$, the Ftable value is 3.19. The comparison of the two gives the results of Fcount $>$ Ftable, namely 275.510> 3.19. Thus, when viewed from its significance value, the test results show that Ho is rejected so that there is an influence between entrepreneurship training and work motivation on interest in entrepreneurship.

When viewed from the comparison between the value of Fcount and Ftable, the test results show that the effect is positive or directly proportional. Therefore, it can be concluded from the results of these tests that the variables of entrepreneurship training and work motivation together (simultaneously) have a positive and significant effect on the entrepreneurial interest of the younger generation of Selimbau. The output of R Square is 0.920 . This implies that the variables of entrepreneurship training and work motivation are simultaneously related to the interest in entrepreneurship, which is $92 \%$.

\section{DISCUSSION}

The Effect of Entrepreneurship Training (X1) towards Entrepreneurial Interest (Y)

The result of entrepreneurship training shows that tcount is greater than ttable. Thus, alternative hypothesis (Ha) is accepted that is there is an effect of entrepreneurship training towards entrepreneurial interest. The magnitude of the direct effect of entrepreneurship interest towards entrepreneurial interest is $\mathrm{X} 1$ ? $\mathrm{Y}=\mathrm{?} \mathrm{YX} 1=(0.889 \mathrm{x} 0.889)$ $=0.7903=79.03 \%$. The results of the calculations show the contribution of the effect of entrepreneurship training towards entrepreneurial interest is $79.03 \%$, meanwhile the rest $(100 \%-79.03 \%=21.07 \%)$ is influenced by other factors that is not studied.

In line with the results of interviews obtained from the younger generation of Selimbau, they get an entrepreneurship training especially from surrounding families, providing experience with knowledge of how to do a successful business, so that they start to believe they are able to apply it, thus giving hope and growing confidence or interest in entrepreneurship. The result is that $78 \%$ of younger generation of Selimbau has succeeded in the arowana fish pond business. In line with the results of this study, there is a supporting research as following: Valerio, Parton, \& Robb (2014, p. 22) argues that "Entrepreneurship training program is a program that tends to focus on building knowledge and skills in preparation explicitly to start a business, which in this training program, leads the participants to engage in practice. Likewise, the results of research by Yuwono \& Partini (2008) entitled "The Influence of Entrepreneurship Training on the Growth of Entrepreneurial Interest". This research shows that the value of $t$ is 2.910 that means there is a significance difference of entrepreneurial interest between before and after the training. Hertawan (2017), in his research result of "The Effect of Independent Entrepreneurship Training of Rabbit Farming towards Entrepreneurial Interest in Rabbit Farmers in Local Transmigration in Sempurmayung, West Java". This study shows, according to hypothesis testing it is known that training needs, training targets, training curricula, trainers, training participant, training implementation and training evaluation have a significant effect towards entrepreneurial interest, namely by $78 \%$. Firdaus \& Hasanah (2018) entitled "The Effect of Entrepreneurship Training and Education towards Entrepreneurial Motivation for Disabilities Person". This study indicates the importance of integrate the entrepreneurship education training as motivation to try and develop a business. This study also proves that $78 \%$ of people with disabilities choose to the type of entrepreneurship based on their interest and expertise.

A number of studies have clearly shown that there is a significant effect that the entrepreneurship training is able to generate entrepreneurial interest, so that the results of the training followed by the younger generation of Selimbau can foster entrepreneurial interest skills to prepare the business to be run.

\section{The Effect of Work Motivation (X1) towards Entrepreneurial Interest (Y)}

The direct effect of work motivation towards entrepreneurial interest is: $\mathrm{X} 2 \rightarrow \mathrm{Y}=\rho \mathrm{YX} 2=(0.888 \mathrm{x} 0.889)$ $=0.780=79 \%$. The contribution of the influence of work motivation on interest in entrepreneurship is $79 \%$, meanwhile the rest $(100 \%-79 \%)=21 \%)$ is influenced by other factors that are not studied. The effect of work motivation towards the entrepreneurial nterest in the younger generation of Selimbau is supported by the opinions of several key informant, that the work motivation for entrepreneurship for the Selimbau young generation is very high. They are very enthusiastic about trying to imitate successful businesses, so that work motivation arises along with the knowledge they get. 
This means that their work motivation has a positive effect towards entrepreneurial interest. The effect of work motivation towards entrepreneurship interest is supported by the following opinions:

The opinion of Munandar (2014) that a person's work motivation can be more proactive or reactive. In proactive work motivation, people will try to improve their abilities according to what their job demands and will try, find, and create opportunities where they can use their abilities to be able to perform high performance. On the other hand, the work motivation of a reactive person tends to wait for an effort or an offer from his / her environment. They will only want to work if they are pushed, forced (from outside themselves) to work.

Noviantoro (2017) entitled "The Influence of Entrepreneurial Knowledge towards Entrepreneurial Motivation, and Family Environment towards Entrepreneurial Interest in Accounting Students", based on entrepreneurial motivation variables obtained by $t$ count of 23.681 greater than $t$ table of 1.65473 while the significance value of 0.0000 is smaller than 0.05 . This shows that entrepreneurial motivation has a positive effect on interest in entrepreneurship. This means that the greater the entrepreneurial motivation, the higher the student's entrepreneurial interest.

Saputri, Hari, \& Arief (2016) entitled "The influence of Entrepreneurial Motivation towards Entrepreneurial Interest Through Learning Achievement in Entrepreneurship Subjects of 11th grade students of SMK Negeri 1 Kraksaan". In this study, the value of entrepreneurial motivation coefficient $(\mathrm{X})$ is 0.273 , it means that every increase of one unit of entrepreneurial motivation $(\mathrm{X})$ will increase 0.273 entrepreneurial interest (Y) assuming other variables are fixed.

Mahesa (2012) entitled "Analysis of Motivational Factors Affecting Entrepreneurial Interest" shows that the variables of tolerance for risk, self-success in entrepreneurship and the desire to be free to work have a positive effect on student interest in entrepreneurship.

A number of studies have clearly shown that there is a greater influence of having work motivation towards interest in entrepreneurship. This shows that entrepreneurial motivation has a positive effect on interest in entrepreneurship. This means that the greater the motivation for entrepreneurship, the higher the entrepreneurial interest will be.

\section{The Effect of Entrepreneurship Training (X1) and Work Motivation (X2) towards Entrepreneurial Interest (Y)}

Entrepreneurship training and work motivation have an effect towards interest in entrepreneurship by $92 \%$. In line with the opinion of the Selimbau young generation that has carried out entrepreneurship training, it has an effect on entrepreneurial interest. Likewise, the work motivation that exists in the Selimbau young generation who strive to apply some entrepreneurial skills is increasingly increasing the entrepreneurial interest. The training makes the Selimbau young generation has skills of how to do entrepreneurship. In addition, that they have strong motivation and willingness to do business, thus it increases their interest in entrepreneurship. These findings are in line with several opinions as follows:

Suryana (2006, p. 18) states that "Entrepreneurial interest is the tendency of someone's heart to be interested in creating a business which then organizes, manages, takes risks and develops the business he creates".
Fostering entrepreneurial interest can explore someone's potential. It shows that entrepreneurial motivation has a positive effect towards entrepreneurial interest. This means that the greater the motivation for entrepreneurship, the higher the entrepreneurial interest will be.

Pitiasari (2016) entitled "The Effect of Entrepreneurship Training, Motivation and Family Environment on Entrepreneurial Interest in Management Study Program Students, Faculty of Economics, Nusantara University PGRI Kediri". In this study, it shows a significance value of 0.041 which is smaller than 0.05 , which means that partially entrepreneurial training has a significant effect towards entrepreneurial interest, meaning that the better and more conducive the training is, the more students have a high and optimal interest in entrepreneurship.

Koranti (2013) entitled "Analysis of the Influence of External and Internal Factors on Entrepreneurial Interest". This study found a positive significant influence of internal factors (personality and motivation) towards entrepreneurial interset. Such as the influence of family environment, motivation and personality towards entrepreneurial interest through self-efficacy, thus the higher the effect on entrepreneurial interest.

Ferreira, Fernandes, \& Ratten (2017) entitled "Entrepreneurial Intention Among Engineering Students: The Role Entrepreneurship Education" shows positive results that entrepreneurship education can foster entrepreneurial interest that is able to create their own business and be able to create jobs. Entrepreneurship training and work motivation have an effect on the interest in entrepreneurship carried out by the younger generation of Selimbau which clearly shows that there is a positive effect between entrepreneurship training and work motivation towards entrepreneurial interest.

\section{CONCLUSIONS}

There is a significant effect between entrepreneurship training towards entrepreneurial interest by $79.03 \%$ with a positive relation. This means, the presence of entrepreneurship training makes the entrepreneurial interest of the younger generation of Selimbau has increased and has an impact on the entrepreneurship training that has been carried out.

(1) There is a significant effect between work motivation towards entrepreneurial interest by $79 \%$ with a positive relationship. This means that there is an increase in work motivation for the younger generation of Selimbau towards their entrepreneurial interest.

(2) There is a significant effect between entrepreneurship training and work motivation towards entrepreneurial interest by $92 \%$. This shows that the entrepreneurial interest of the younger generation of Selimbau has increased due to entrepreneurship training and work motivation. The better the entrepreneurial knowledge obtained and the higher the confidence of an entrepreneurship can be done, will increase a strong work motivation to implement it and ultimately generate the entrepreneurial interest.

(3) The entrepreneurial interest is increasing because the Selimbau young generation has knowledge or skills regarding entrepreneurship. This knowledge makes the Selimbau young generation, Suhaid District, Kapuashulu Regency has a high willingness or work motivation by considering taking the least risk to implement the knowledge of entrepreneurial skills by building a business place of arowana fish pond. 


\section{ACKNOWLEDGEMENTS}

We give thanks to the University of Tanjungpura Pontianak, West Kalimantan for support and funding, and to all parties involved in this research.

\section{REFERENCES}

[1] Djamarah, S. B. (2015). Psikologi Belajar. Jakarta: Rineka Cipta.Dorgan, E. (2015).

[2] The Effect of Entrepreneurship Education on Entrepreneurial Intentions of University Students in Turkey. Ekonomitri Ve Istatistik, 1(23), 79-93. Retrieved

from

https://www.researchgate.net/publication/320474 395_THE_EFFECT_OF_ENTREPRENEURSHIP_EDUCA TION Ferreira, J. J., Fernandes, C. I., \& Ratten, V. (2017).

[3] The Influence of Entrepreneurship Education on Entrepreneurial Intentions. In M. Peris-Ortiz, J. A. Gómez, J. M. Merigó-Lindahl, \& C. Rueda-Armengot (Eds.), Innovation, Technology, and Knowledge Management (pp. 19-34). Springer International Publishing. Firdaus, V., \& Hasanah, H. (2018).

[4] Pengaruh Pelatihan dan Pendidikan Kewirausahaan terhadap Motivasi Berwirausaha pada Penyandang Disabilitas di Kabupaten Jember. Fenomena, 17(2), 263-286. Retrieved from https://www.researchgate.net/publication/330105 224_Jurnal_Fenomena_2018 Hertawan, T. (2017).

[5] Pengaruh Pelatihan Kewirausahaan Mandiri Ternak Kelinci Terhadap Minat Berusaha Kelompok Tani Ternak Kelinci di Transmigrasi Lokal Sempurmayung Jawa Barat. Bandung: Universitas Telkom. Retrieved from https://openlibrary.telkomuniversity.ac.id/pustaka /140777/pengaruh-pelatihan-kewirausahaanmandiri-ternak-kelinci-terhadap-minat-berusahakelompok-tani-ternak-kelinci-di-transmigrasi-lokalsempurmayung-jawa-barat.html

[6] Koranti, K. (2013). Analysis of the Influence of External Factors and Internal Against the Interest in Entrepreneurship. Proceeding rapidly (psychology, economics, literature, architecture and civil engineering), 5. Bandung.

[7] Kuratko, D. F. (2018). Introduction to Entrepreneurship Eighth Edition. Mason, OH, United States: Cengage Learning.

[8] Kurniati, E. D. (2018). Kewirausahaan Industri. Yogyakarta: Deepublish.

[9] Mahesa, A. D. (2012). Analisis Faktor-Faktor Motivasi Yang Mempengaruhi Minat Berwirausaha. Diponegoro Jounal Of Management., 1(1), 130-137. Retrieved from http://ejournal-s1.undip.ac.id/index.php/dbr.
[10] Mathis, R., \& Jackson, J. (2016). Manajemen Sumber Daya Manusia. (J. Sadeli, \& B. P. Hie, Trans.) Jakarta: Salemba Empat.

[11] Munandar. (2014). Psikologi Kepribadian. Jakarta: Raja Grafindo Persada.

[12] Notoatmodjo, S. (2009). Pengembangan Sumber Daya Manusia. Jakarta: Rineka Cipta.

[13] Noviantoro, G. (2017). Pengaruh Pengetahuan Kewirausahaan, Motivasi Berwirausaha dan Lingkungan Keluarga Terhadap Minat Berwirausaha pada Mahasiswa Akuntansi Fakultas Ekonomi Universitas Negeri Yogyakarta. Yogyakarta: Universitas Negeri Yogyakarta. Retrieved from https://eprints.uny.ac.id/50980/1/Skripsi_Galih\%2 0Noviantoro_13812141046.pdf

[14] Pitiasari, D. (2016). Pengaruh Pelatihan Kewirausahaan, Motivasi Dan Lingkungan Keluarga Terhadap Minat Berwirausaha Pada Mahasiswa Prodi Manjemen Fakultas Ekonomi Universitas Nusantara PGRI Kediri. Kediri: Universitas Nusantara PGRI.

[15] Saputri, H., Hari, M., \& Arief, M. (2016). Pengaruh Motivasi Berwirausaha Terhadap Minat Berwirausaha Melalui Prestasi Belajar Mata Pelajaran Kewirausahaan Siswa Kelas XI SMK Negeri 1 Kraksaan. Jurnal Pendidikan Bisnis dan Manajemen, 2(2), 123-132. Retrieved from http://journal2.um.ac.id

[16] Sukmadinata, N. S. (2017). Metode Penelitian Pendidikan. Bandung: Remaja Rosdakarya.

[17] Suryana. (2006). Kewirausahaan, Pedoman Praktis, Kiat dan Proses Menuju Sukses. Jakarta: Salemba Empat.

[18] Valerio, A., Parton, B., \& Robb, A. (2014). Entrepreneurship Education and Training Program Around the World: Dimenssion for Success. Washington, D.C: The World Bank.

[19] Yuwono, S., \& Partini. (2008). Pengaruh Pelatihan Kewirausahaan terhadap Tumbuhnya Minat Berwirausaha. Jurnal Penelitian Humaniora, 9(2), 119-127. Retrieved from https://publikasiilmiah.ums.ac.id/xmlui/bitstream/ handle/11617/595/1.\%20susatyo.pdf?sequence=1 \&isAllowed $=y$

[20] Zimmerer, T. W., Scarborough, N. M., \& Wilson, D. (2008). Kewirausahaan dan Manajemen Usaha Kecil. Jakarta: Salemba Empat. 